\title{
EVALUATION OF ANXIETY, DEPRESSION AND STRESS SYMPTOMS IN MEN WITH PROSTATE CANCER DURING THE PREOPERATIVE PERIOD
}

\author{
AVALIAÇÃO DOS SINTOMAS DE ANSIEDADE, DEPRESSÃO E ESTRESSE EM \\ HOMENS COM CÂNCER DE PRÓSTATA NO PERÍODO PRÉ-OPERATÓRIO
}

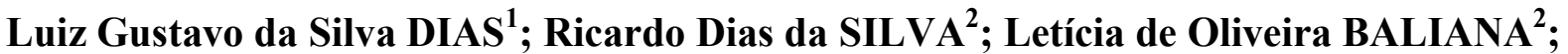 Lorena Campos MENDES ${ }^{3}$; Elizabeth BARICHELLO ${ }^{4}$}

1. Nurse. Federal University of Triangulo Mineiro - UFTM; Uberaba, MG, Brazil; 2. Nurse. Master student of the Graduate Program in Health Care - PPGAS, Federal University of Triângulo Mineiro - UFTM, Uberaba, MG, Brazil; 3. Nurse. PhD student of the Graduate Program in Health Care - PPGAS of the Federal University of Triângulo Mineiro - UFTM, Uberaba, MG, Brazil; 4. PhD in Nursing, Associate Professor of Nursing and of the Stricto Sensu Graduate Program in Health Care at UFTM, Uberaba, MG, Brazil. lizabarichello@hotmail.com.

\begin{abstract}
Prostate cancer is the second most common type of cancer among men, being considered a cancer of the elderly because about three quarters of cases worldwide occur in individuals aged 65 and over. Anxiety, depression and stress are three emotional states understood as psychological morbidity factors, and they interfere with the patient's adaptation to the diagnosis. The present study aimed to identify anxiety, depression and stress levels in men with prostate cancer, describing sociodemographic and clinical characteristics and investigating whether the influence of such characteristics on the emotional symptoms of patients is significant. Cross-sectional study with a quantitative approach performed in two public hospitals with patients preoperatively for prostatectomy. Two instruments were used, one covering sociodemographic and clinical aspects of the patients, and the other was the Depression Anxiety and Stress Scale (DASS-21)Short Form. In the statistical analysis, the Pearson correlation test and the Mann-Whitney U test were used to evaluate the variables of interest, considering the significance level of 0.05 . As a preliminary study, 31 patients were interviewed. The results indicated a predominant age of 60 years or older $(72.4 \%), 71 \%$ of men had low level of education, and $51.6 \%$ did not have partner. The mean scores obtained in the DASS-21 were $2.84(\mathrm{SD}=$ $3.925)$ for depression; $3.68(\mathrm{SD}=3.655)$ for anxiety; and $6.71(\mathrm{SD}=6.92)$ for stress. The results revealed no significant correlation between these constructs and the variables of interest. However, a descriptive analysis of the data showed a minimal correlation of anxiety $(r=0.191)$ and stress $(r=0.149)$ with the numerical variable time since diagnosis. In conclusion, the results presented important questions related to prostate cancer diagnosis, involving patients' marital status, religion and cancer staging.
\end{abstract}

KEYWORDS: Prostate neoplasms. Depression. Psychological stress. Anxiety. Preoperative Care.

\section{INTRODUCTION}

Cancer is the name for a group of more than 100 diseases that have in common the disordered growth of cells that can invade organs and tissues of the human body. The uncontrollable and rapid division of these cells confers a characteristic of aggression, determining the accumulation of cancer cells and ultimately the formation of tumors. These cancer cells can spread to other regions of the body in a process called metastasis (BRASIL, 2019).

Prostate Cancer (PC) is the second most common type of cancer among men, behind only non-melanoma skin cancer. According to national estimates, the number of PC cases for 2018 was 68,220 cases, corresponding to an estimated risk of 68.22 new cases per 100,000 men (BRASIL, 2019). According to Watts et al. (2015), the number of men diagnosed with PC continues to increase every year as a result of increased Prostate Specific Antigen (PSA) testing and the process of population aging.

Depression and anxiety are considered emotional symptoms that together may provide a multifaceted description of the psychological distress experienced by PC patients (SHARPLEY et al., 2018). Moreover, the surgical treatment of PC is usually influenced by the onset of these symptoms, especially when they are related to surgical side effects such as extended hospitalization periods, pain, sexual dysfunction and urinary incontinence (PASTORE et al., 2018). As to the phenomenological aspect, anxiety can be understood as a condition that involves feelings of fear and worry, while depression encompasses other emotional aspects, such as apathy, grief and hopelessness (MARCOLINO et al., 2007).

In this light, psychological stress has been highlighted as another important factor that is 
associated with a low adaptation of patients to the diagnosis of PC. Stress is considered as a condition that is usually influenced by emotional stimulation, involving feelings of irritability, fatigue and tension (CURTIS; GROARKE; SULLIVAN, 2014).

In the early stages of PC, patients typically participate in the choice of treatment, which is important because each type of therapy has unique and potential adverse effects on the patient (LEHTO et al., 2015). Some patients diagnosed with PC opt for a disease monitoring strategy known as active surveillance of tumor that aims to delay or completely prevent cancer treatment in men who are candidates for some type of active cancer therapy (TOSOIAN et al., 2016).

In addition to the PSA testing, there has been an increase in the number of requests for histopathological exams, such as prostate biopsy. The increasingly frequent repetition of tests, as well as variations in PSA levels, has generated indecision regarding the actual indication for biopsy procedures (KOBAYASHI; NUKUI; KAMAI, 2017). Although there is considerable focus on the consequences of the disease, there is a relative scarcity of empirical data about the psychological impact of a prostate biopsy, which is noteworthy because, according to the qualitative literature, men perceive the prostate biopsy procedure as a stressful event (GROARKE et al., 2018).

In a study conducted by Kohler et al. (2014) to evaluate the prevalence of psychological distress and the mode of adaptation to the disease before and after surgery, it was observed that before the surgery, the adaptive effort presented by the patients towards the disease was more frequently associated with anxiety compared to depression levels. Therefore, it is essential for healthcare professionals to understand how these patients will receive such a diagnosis and be fully aware of the emotional impact of methods and procedures of investigation of PC so that they can provide information about the disease and offer psychological support at this time (GROARKE et al., 2018).

Despite the focus that has been given to health-related quality of life among PC patients, little attention and importance has been given to aspects of psychological well-being in these patients (PUNNEN et al., 2013). Thus, this study aimed to identify the levels of anxiety, depression and stress in men with PC in the preoperative period for prostatectomy; describe the sociodemographic and clinical characteristics of these patients; and verify if the influence of such characteristics have a significant relation with the emotional symptoms of the patients.

\section{MATERIAL AND METHODS}

This is a descriptive cross-sectional quantitative study (POLIT; BECK, 2011). The study population consisted of a maximized convenience sample of patients diagnosed with PC and who were in the preoperative period for prostatectomy, aged 18 years or older, admitted to two health institutions: a university hospital, specifically in the surgical clinic sector, and a public hospital specializing in cancer care. Both institutions are located in the Triângulo Mineiro region of Minas Gerais.

This study was approved by the Research Ethics Committee with Opinion 2,592,133. The participants were previously asked to sign the Informed Consent Form. The research followed all planned steps for studies involving human subjects in accordance with resolution 466/12. Data collection occurred from June 2018 to February 2019.

For data collection, two instruments were applied: the first containing sociodemographic and clinical questions, elaborated by the authors, and the second, the Depression, Anxiety and Stress Scale DASS-21. The sociodemographic information collected was: age (in full years), origin, profession/occupation, religion, individual monthly income (IMI) and family monthly income (FMI), education level and marital status. The clinical data investigated were: date of admission of the patient to the surgical clinic sector, tumor staging (not specified/not informed, initial, intermediate or advanced), time since diagnosis of PC (in months), presence of metastasis, type of cancer treatment and number of sessions proposed.

The Depression, Anxiety and Stress Scale DASS 21 is a validated data collection instrument for the Brazilian population, consisting of 21 questions that assess mood changes. It is a set of three four-point, self-answered Likert-type subscales: not applied at all (0 points); applied to some degree or for a short time (1 point); applied to a considerable degree, or for a good part of the time ( 2 points); applied a lot, or most of the time ( 3 points). Each subscale is composed of seven items whose function is to evaluate the emotional states of each interviewee: depression, anxiety and stress (VIGNOLA; TUCCI, 2014).

Questions 3, 5, 10, 13, 16, 17 and 21 correspond to the depression scale. Questions 2, 4, $7,9,15,19$ and 20 refer to the anxiety scale. The remaining questions $(1,6,8,11,12,14$, and 18) correspond to the stress scale. The total scores of each subscale are obtained from the sum of the 
questions of each subscale and its multiplication by 2 (VIGNOLA; TUCCI, 2014). In the present study, the following acronyms were adopted for the Depression, Anxiety and Stress Scores, respectively: ESC-D; ESC-A; and ESC-E.

The collected data were entered into a spreadsheet (Microsoft Office Excel for Windows $\left.{ }^{\circledR}\right)$, tabulated, analyzed and later transported to the IBM Software, Statistical Package for the Social Sciences (SPSS), version 20.0, run on Windows ${ }^{\circledR}$ for processing the data. Inferential procedures were performed considering a significance level of $5 \%$.

First, a descriptive analysis of categorical and numerical variables (age, educational level, marital status, monthly income, tumor staging, time since diagnosis, etc.) was performed, using absolute frequency and percentage measures. To measure and analyze the scores of the constructs: depression, anxiety and stress, measures of central tendency and variability were used.

In order to evaluate the association between dichotomous predictors (the variables: religion, marital status and tumor staging) with depression, anxiety and stress scores, and to verify whether the results obtained were statistically significant, two- parameter nonparametric tests for independent samples were performed using the Mann-Whitney U Test. To correlate a numerical variable (time since diagnosis) with depression, anxiety and stress symptom scores, the Pearson Correlation Test (r) was used in order to verify statistical evidence between the variable of interest and the above mentioned constructs.

\section{RESULTS}

Thirty-one patients who were in the preoperative period for elective prostatectomy were interviewed.

Of the 31 patients treated, most came from other cities $(74.2 \%)$, with a prevalent age greater than or equal to 60 years $(74.2 \%)$, which shows a greater predominance of elderly people. The prevalent religion was Catholic, comprising $71 \%$ of the sample, and, regarding marital status, $51.6 \%$ of the patients had no partner. Among the patients, $71 \%$ had a low level of education (ranging from Incomplete Elementary School to Incomplete High School) and $25.8 \%$ had completed High School or higher education $(25.8 \%)$. Data are presented in Table 1.

Table 1. Sociodemographic characterization of patients with PC admitted to two public hospitals in the preoperative period of prostatectomy.

\begin{tabular}{lll}
\hline Characteristics & n & \% \\
\hline Age (in full years) & 8 & 25.8 \\
50 to 59 & 23 & 74.2 \\
$\geq 60$ & 8 & 25.8 \\
Origin & 23 & 74.2 \\
Uberaba & & \\
Other cities & 22 & 71 \\
Religion & 9 & 29 \\
Catholic & & \\
Other & 18 & 58.1 \\
Profession/Occupation & 13 & 41.9 \\
Retired & & \\
Other & 15 & 48.4 \\
IMI & 9 & 29 \\
Up to 1 MW * & 6 & 19.4 \\
1 to 2 MW & 1 & 3.2 \\
2 to 4 MW & & \\
More than 4 MW & 10 & 32.3 \\
FMI & 10 & 32.3 \\
Up to 1 MW & 5 & 16.1 \\
1 to 2 MW & 6 & 19.4 \\
2 to 4 MW & & \\
More than 4 MW & 1 & 3.2 \\
Level of education & 15 & 48.4 \\
No schooling/illiterate & & \\
Incomplete elementary & & \\
& &
\end{tabular}


Complete elementary

Incomplete high school

Complete high school

Incomplete higher education

Complete higher education

\section{Marital status}

Married

Not married

Divorced

Widower

$\begin{array}{ll}3 & 9.7 \\ 4 & 12.9 \\ 6 & 19.4 \\ 1 & 3.2 \\ 1 & 3.2\end{array}$

$15 \quad 48.4$

$5 \quad 16.1$

$5 \quad 16.1$

$6 \quad 19.4$

Legend - $^{\mathrm{a}}$ : IMI = Individual Monthly Income; ${ }^{b}$ : FMI = Family Monthly Income; *: MW= Minimum Wage(s).

Regarding the stage of cancer in which the patient was, most of the interviewed men $(n=25 /$ $80.6 \%$ ) had been diagnosed with the initial phase of PC. No interviewee had metastatic condition, and as to the time elapsed since diagnosis of the disease until the surgical procedure, most $(51.7 \%)$ had a recent interval, ranging from 2 to 6 months. The clinical characterization of the patients is illustrated in Table 2.

Table 2. Clinical characterization of patients with PC admitted to two public hospitals in the preoperative period of prostatectomy.

\begin{tabular}{lll}
\hline Characteristics & $\mathbf{n}$ & $\mathbf{\%}$ \\
\hline Tumor staging & 1 & \\
Not specified/not informed & 25 & 3.2 \\
Initial & 5 & 80.6 \\
Advanced & & 16.1 \\
Time since diagnosis (in months) & 2 & \\
2 & 5 & 6.5 \\
4 & 2 & 16.1 \\
5 & 7 & 6.5 \\
6 & 1 & 22.6 \\
7 & 4 & 3.2 \\
8 & 3 & 12.9 \\
9 & 1 & 9.7 \\
10 & 1 & 3.2 \\
13 & 1 & 3.2 \\
14 & 2 & 3.2 \\
15 & 1 & 6.5 \\
18 & 1 & 3.2 \\
22 & & 3.2 \\
Presence of metastasis & 0 & \\
Yes & 31 & 0 \\
No & 100 \\
\hline
\end{tabular}

In Table 3, it is possible to observe the statistics in relation to the measures of central tendency obtained and the scores of depression, anxiety and stress. Statistically, it was not possible to make inferences regarding the changes in anxiety, depression and stress symptoms likely to be experienced by patients with $\mathrm{PC}$ in the preoperative phase of prostatectomy, since the sample was small and the score values obtained in each scale were not significant.

It was also observed that the mean score for depression was 2.8 points; the mean for anxiety of
3.7 points; and the mean for stress was 6.7 points. According to the interpretation of the DASS-21 (VIGNOLA; TUCCI, 2014), these values show that patients were generally classified as 'normal' for symptoms of depression, anxiety and stress.

However, it is necessary to emphasize that, descriptively, the patients presented alterations in the three investigated symptoms: four patients presented moderate level of anxiety; three were classified as presenting mild depression, and two moderate stress. However, none of the patients presented high levels of the evaluated symptoms. 
Table 3. Statistics of the relationship between measures of central tendency and Depression, Anxiety and Stress scores for patients with PC admitted to two public hospitals in the preoperative period of prostatectomy.

\begin{tabular}{llll}
\hline Statistics & DASS-21 ESC-D & DASS-21 ESC-A & DASS-21 ESC-E \\
\hline Mean & 2.84 & 3.68 & 6.71 \\
Median & 0 & 2 & 4 \\
Standard deviation & 3.925 & 3.655 & 6.92 \\
Minimum & 0 & 0 & 0 \\
Maximum & 14 & 12 & 22 \\
\hline
\end{tabular}

Another pertinent issue to be considered is that, despite the absence of statistically significant results, there was an association of three dichotomous variables (religion, marital status and tumor staging) with scores obtained from the evaluation of symptoms of depression, anxiety and stress. Tables 4,5 and 6 , shown below, reveal this association.

Table 4. Association of dichotomous variables with depression symptom scores presented by PC patients admitted to two public hospitals in the preoperative period of prostatectomy.

\begin{tabular}{|c|c|c|c|c|c|c|}
\hline \multirow[t]{2}{*}{ Characteristics } & \multicolumn{6}{|c|}{ Depression score } \\
\hline & $\operatorname{Min}^{\mathrm{a}}$ & $\operatorname{Max}^{b}$ & Mean & Median & $\mathbf{S D}^{\mathrm{c}}$ & $\mathbf{p}^{*}$ \\
\hline Religion & & & & & & 0.365 \\
\hline Catholic & 0 & 14 & 3.18 & 2 & 4.078 & \\
\hline Others & 0 & 10 & 2 & 0 & 3.606 & \\
\hline Marital status & & & & & & 0.532 \\
\hline With partner & 0 & 6 & 2.67 & 2 & 2.69 & \\
\hline Without partner & 0 & 14 & 3 & 0 & 4.899 & \\
\hline Tumor staging & & & & & & 0.619 \\
\hline Initial & 0 & 14 & 2.88 & 0 & 4.206 & \\
\hline Others & 0 & 6 & 2.67 & 2 & 2.733 & \\
\hline
\end{tabular}

Table 5. Association of dichotomous variables with anxiety symptom scores presented by PC patients admitted to two public hospitals in the preoperative period of prostatectomy.

\section{Characteristics}

\section{Religion}

Catholic

Others

\section{Marital status}

With partner

Without partner

Tumor staging

Initial

Others

\section{Anxiety score}

$\operatorname{Min}^{\mathrm{a}} \operatorname{Max}^{\mathrm{b}}$ Mean Median

3.82

3.33

$0 \quad 12$

$0 \quad 10$

$0 \quad 8$

$0 \quad 12$

3.33

4

3.28

5.33 p*

0.621

0.978

0.174

Legend $-{ }^{\mathrm{a}}$ : Min $=$ Minimum; ${ }^{\mathrm{b}}:$ Max $=$ Maximum; ${ }^{\mathrm{c}}: \mathrm{SD}=$ Standard Deviation; ${ }^{*}: \mathrm{p}=$ significance value (Mann-Whitney U Test). 
Table 6. Association of dichotomous variables with stress symptom scores presented by PC patients admitted to two public hospitals in the preoperative period of prostatectomy.

\begin{tabular}{lrrrrrl}
\hline Characteristics & \multicolumn{7}{c}{ Stress score } \\
\hline Religion & Min $^{\mathrm{a}}$ & $\mathbf{M a x}^{\mathrm{b}}$ & Mean & Median & SD $^{\mathbf{c}}$ & $\mathbf{p}^{*}$ \\
Catholic & & & & & & 0.436 \\
Others & 0 & 22 & 6.91 & 4 & 6.524 & \\
Marital status & 0 & 22 & 6.22 & 0 & 8.212 & \\
With partner & & & & & & 0.976 \\
Without partner & 0 & 14 & 6.53 & 4 & 6.163 & \\
Tumor staging & 0 & 22 & 6.88 & 4 & 7.762 & \\
Initial & & & & & & 0.429 \\
Others & 0 & 22 & 6.16 & 4 & 6.581 & \\
\hline
\end{tabular}

Legend $^{\text {a }}$ : Min = Minimum; ${ }^{\text {b }}$ Max = Maximum; c: SD = Standard Deviation; *: $\mathrm{p}$ = significance value (Mann-Whitney U Test).

Descriptively, there was a slightly significant difference in the depression score with respect to marital status, as the mean score of men with partners was 2.6, while that of those who did not have a partner (single, divorced, widowers) was 3.0.

Regarding anxiety scores, the variable tumor staging gained prominence; the mean score of men with early-stage PC was 3.28 points, while that of those who were in other stages (not specified, intermediate, advanced) was 5.33. For stress scores, it was noted that their association with the variable tumor staging was significant, resulting in a moderate divergence of this symptom among patients who were in the early phase of the disease $($ mean $=6.16)$ and those in other stages $($ mean $=9)$.

Regarding the value of statistical significance, represented by the letter $" p "$ and exposed in the tables below, it was not possible to infer considerable results, because the " $p$ - values" obtained in the Mann-Whitney $U$ test were higher than $0.05(\mathrm{p}>0.05)$ and, therefore, for statistical reasons, these values did not reveal relevant information about changes in symptoms of depression, anxiety and stress. However, as this is a descriptive investigation, the proper study allowed the visualization of some important points about the levels of the investigated symptoms in the evaluation of this preliminary sample, such as the information mentioned above

Regarding the numerical variable time since diagnosis and anxiety, depression, and stress scores, the correlation test did not reveal statistically significant information. Table 7 below shows the weak correlation between the time factor (in months) since the patient was diagnosed with PC and anxiety and stress symptom scores $(r=0.191$ and $\mathrm{r}=0.149$, respectively).

The value of " $\mathrm{r}$ " for depression symptom scores $(r=-0.132)$ revealed a negative correlation between the depression subscale and the variable of interest. When analyzing the value of statistical significance $(p)$, there was no possibility of inferences of data resulting from this correlation that can be considered statistically supportive. On the other hand, descriptively, anxiety and stress symptoms had a correlation with the variable time since diagnosis, although minimal.

Table 7. Correlation of the variable time since diagnosis with depression, anxiety and stress symptom scores for patients with PC admitted to two public hospitals in the preoperative period of prostatectomy.

\begin{tabular}{llll}
\hline Time since diagnosis & Depression & Anxiety & Stress \\
\hline $\mathbf{r}$ & $-0,132$ & 0,191 & 0,149 \\
$\mathbf{p}$ & 0,48 & 0,303 & 0,423 \\
$\mathbf{N}$ & 31 & 31 & 31 \\
\hline Legend $^{\mathrm{a}}: \mathrm{r}=$ Pearson Correlation Value; ${ }^{\mathrm{b}}: \mathrm{N}=$ Sample Number; $: \mathrm{p}=$ value of statistical significance.
\end{tabular}

Legend $-{ }^{\mathrm{a}}: \mathrm{r}=$ Pearson Correlation Value ${ }^{\mathrm{b}}: \mathrm{N}=$ Sample Number; $*: \mathrm{p}=$ value of statistical significance. 


\section{DISCUSSION}

This study described the symptoms of anxiety, depression and stress in male patients diagnosed with PC in the preoperative period of prostatectomy, admitted to two hospital-level health institutions. The symptom scores were correlated with sociodemographic and clinical variables.

In the results, it was found that $74.2 \%$ of men diagnosed with PC were 60 years old or older. This information is consistent with the study by Watts et al. (2015) where it was shown that the cases of PC have been increasing due to the phenomenon of population aging. Given the fact that both PC incidence and mortality rates tend to increase significantly after 50 years of age, age is considered an impacting and well-established risk factor for predisposition to PC (VIEIRA et al., 2012; GOMES; IZIDORO; MATA, 2015).

With regard to spirituality, it is known that, in recent decades, a greater focus has been given to the factor of religiosity and its role as a strategy for coping with cancer (MESQUITA et al., 2013). Of the 31 patients approached in the appropriate study, the vast majority $(\mathrm{n}=22)$ had Catholicism as religion. This information corroborates data presented in the study by Gomes, Izidoro and Mata (2015), which found that more than half of the respondents $(79.3 \%)$ were Catholics. Thus, it is necessary to emphasize that religion is an important factor in the process of adaptation to the disease, consequently playing a protective role against the psychological morbidity experienced by many patients (MESQUITA et al., 2013).

In the present study, regarding the variable educational level, there was a higher prevalence of patients with low education ( $71 \%$ ), and only $25.8 \%$ of the respondents had a higher level of schooling. This finding corroborates the results of a study by Quijada et al. (2017), which showed a higher prevalence of men with low level of education (79.3\%).

Regarding the test of association of dichotomous variables with the symptom scores, there was a small descriptive difference in marital status in relation to the mean obtained for each symptom, which was slightly higher among men who had no partners. This is an important fact to be taken into consideration, as it corroborates a study conducted in China to determine the factors that interfere with the Health Related Quality of Life (HRQoL) of patients with PC, which concluded that marital status is a determining variable in the HRQoL of men with the disease (KAO et al., 2015).
In our research, more than half of the patients were in the early stage of the disease $(80.6 \%)$, data that may demonstrate the importance of early diagnosis of PC. It is found in the literature that PC screening is a controversial issue, considering that there may be an excessive increase in the number of diagnoses and therapies without impact on patient survival, specifically when it comes to PC. According to the European Society of Urology (EAU), early detection of PC based on an individualized strategy of guidance on risk of $\mathrm{PC}$ is recommended (DAMIÃO et al., 2015).

In the present research, none of the 31 patients had metastatic condition. This is extremely important and should be taken into account, because in general, prostate tumors have a gradual growth, taking approximately 15 years to reach $1 \mathrm{~cm}$. Linked to this fact, increasingly frequent PSA tests have contributed to an early diagnosis and detection of PC, even before the patient begins to present the classic symptoms of the disease (NOVAES; MOTTA; LUNDGREN, 2015).

It is noteworthy that Ordinance 876/GM/MS, of May 16, 2013 brings as a public policy that patients with malignant neoplasia have the right to undergo the first treatment in the Unified Health System (SUS) within up to 60 days from the diagnosis in pathological report (BRASIL, 2013).

Regarding the statistics of anxiety, depression and stress scores obtained, it is clear that the mean obtained in each subscale was not significant, and it was not possible to make statistical inferences about the prevalence of these symptoms in the population studied. On the other hand, it was descriptively observed slightly considerable means for each subscale. In the study by Ravi et al. (2014), patients undergoing radical prostatectomy did not show significant results of anxiety and depression. However, the authors argue that this finding may be due to the fact that the idea of having the cancer stopped or removed through radical prostatectomy generates a more positive mindset in patients when compared to patientse who undergo cancer monitoring, because the later feel that their disease is not being actively treated.

In the attempt to correlate the variable time since diagnosis with depression, anxiety and stress symptom scores, it was not possible to find conclusive evidence of a significant correlation. However, the descriptive analysis of the " $r$ " values for anxiety and stress $(r=0.191$ and $r=0.149$, respectively) showed a minimal correlation between these symptoms and the variable of interest. Regardless of the time since diagnosis, the initial 
stage of the disease may be related to depression, anxiety and stress symptom scores.

In a study by Souza et al. (2018) focusing on cancer patients, there was no statistically significant correlation between the variable time since diagnosis and depression, anxiety, self-esteem and activation symptoms, except when the correlation was made with the variables level of schooling and number of comorbidities. This information may contribute to other studies involving the variable: time of diagnosis for cancer patients.

The limitations of this study included the size of the sample, the lack of identification of the time interval from the admission of the patient to the date of application of the data instruments, and the absence of a more specific correlation between clinical variables and emotional symptoms in order to observe the progression of these symptoms over time.

The present study described the sociodemographic and clinical profile of patients with PC in the preoperative period in two hospital- level health institutions, which composed a preliminary sample for the appropriate research. Furthermore, this study aimed to identify the levels of anxiety $($ mean $=3.68)$, depression $($ mean $=2.84)$ and stress (mean $=6.71$ ) in these individuals, and although it was not possible to obtain statistically significant conclusions, it was possible to visualize relationships between sociodemographic and clinical constructs and depression, anxiety and stress scores, which allow a relevant analysis.

The results found in this paper constitute evidences that health professionals may include in the investigation of these subjective constructs during the evaluation of patients with $\mathrm{PC}$, and also implement strategies to detect and reduce symptoms of anxiety, depression and/or stress likely to be found in this population. As the diagnosis of PC can bring an intense emotional burden to the patients, it is essential that healthcare professionals provide adequate information about the disease to the clients, and concomitantly offer health care based on comprehensiveness, humanization, and individuality of care.

RESUMO: O câncer de próstata é o segundo tipo de neoplasia mais comum entre os homens, sendo considerado um câncer da terceira idade, uma vez que cerca de três quartos dos casos no mundo ocorrem a partir dos 65 anos. Ansiedade, depressão e estresse são três estados emocionais, entendidos como fatores de morbidade psicológica, que interferem na adaptação do paciente ao diagnóstico. O presente estudo teve como objetivo identificar os níveis de ansiedade, depressão e estresse em homens com câncer de próstata; descrever as características sociodemográficas e clínicas e verificar se a influência de tais características é significativa sobre os sintomas emocionais dos pacientes. Estudo transversal, com abordagem quantitativa, realizado em duas instituições hospitalares públicas com os pacientes no pré-operatório para prostatectomia. Foram utilizados dois instrumentos, referente a questões sociodemográficas e clínicas dos pacientes; e a Escala de Depressão, Ansiedade e Estresse: Forma reduzida - DASS-21. Para a análise estatística, foi realizado o teste de correlação de Pearson, e o teste U de Mann-Whitney para avaliar as variáveis de interesse, considerando-se o nível de significância igual a 0,05 . Tratando-se de um estudo preliminar, foram entrevistados 31 pacientes, onde os resultados apontaram uma idade predominante de 60 anos ou mais $(72,4 \%), 71 \%$ de homens com baixo nível de escolaridade e $51,6 \%$ dos entrevistados não possuíam companheiras. As pontuações médias obtidas pelo instrumento do DASS-21 foram: 2,84 ( $\mathrm{DP}=3,925)$ para depressão; 3,68 ( $\mathrm{DP}=3,655)$ para ansiedade e $6,71(\mathrm{DP}=6,92)$ para estresse. Os resultados não revelaram nenhuma correlação significativa entre esses constructos e as variáveis de interesse. No entanto, ao analisar nossos dados de forma descritiva, conseguimos observar mínimas correlações dos sintomas de ansiedade $(\mathrm{r}=0,191)$ e estresse $(\mathrm{r}=0,149)$ com a variável numérica: tempo desde o diagnóstico. Em conclusão, os resultados apresentaram questões importantes relacionadas ao diagnóstico do câncer de próstata, envolvendo o estado civil dos pacientes, a religião e o estadiamento do câncer.

PALVRAS-CHAVE: Neoplasias da próstata. Depressão. Estresse psicológico. Ansiedade. Cuidados pré-operatórios.

\section{REFERENCES}

BRASIL. Ministério da Saúde. Instituto Nacional do Câncer (INCA). Câncer de próstata. 2019. Disponível em: <http://www2.inca.gov.br/wps/wcm/connect/tiposdecancer/site/home/prostata>. Acesso em: 20 jan. 2019. 
BRASIL. Ministério da Saúde. Portaria $n^{\circ} 876$, de 16 de maio de 2013. Disponível em:

$<$ http://bvsms.saude.gov.br/bvs/saudelegis/gm/2013/prt0876_16_05_2013.html>. Acesso em: 28 set. 2019.

CURTIS, R.; GROARKE, A.; SULLIVAN, F. Stress and self-efficacy predict psychological adjustment at diagnosis of prostate câncer. Scientific Reports, 2014. Disponível em:

$<$ https://www.ncbi.nlm.nih.gov/pmc/articles/PMC4081888/pdf/srep05569.pdf>. Acesso em: 01 out. 2017.

DAMIÃO, R. D.; FIGUEIREDO, R. T.; DORNAS, M. C.; LIMA, D. S.; KOSCHORKE, M. A. B. Câncer de próstata. Revista HUPE, Rio de Janeiro, vol. 14, supl. 1, p. 80-86, ago. 2015. Disponível em:

$<\mathrm{http}: / /$ revista.hupe.uerj.br/detalhe_artigo.asp?id=249>. Acesso em: 17 fev. 2019.

https://doi.org/10.12957/rhupe.2015.17931

GOMES, C. R. J.; IZIDORO, L. C. R.; MATA, L. R. F. Risk factors for prostate cancer, and motivational and hindering aspects in conducting preventive practices. Investigación y Educación en Enfermería. v. 33, n. 3, p. 415-423, 2015. Disponível em: <http://www.scielo.org.co/pdf/iee/v33n3/v33n3a04.pdf $>$. Acesso em: 15 fev. 2019.

GROARKE, A.; CURTIS, R.; WASH, D. M. J.; SULLIVAN, F. J. What predicts emotional response in men awaiting prostate biopsy?. BMC Urology. v. 18, n. 1, apr. 2018. Disponível em:

$<$ https://www.ncbi.nlm.nih.gov/pmc/articles/PMC5922026/>. Acesso em: 15 mar. 2019.

https://doi.org/10.1186/s12894-018-0340-9

KAO, Y. L.; TSAI, Y. S.; OU, F. Y.; SYU, Y. J.; OU, C. H.; YANG, W. H.; CHENG, L. C.; TZAI, T. S.; WANG, J. D. Determinants of quality of life in prostate cancer patients: A single institute analysis. Urological Science. v. 26, n. 4, p. 254-258, 2015. Disponível em:

$<$ https://www.sciencedirect.com/science/article/pii/S1879522615003632>. Acesso em: 10 mar. 2019. https://doi.org/10.1016/j.urols.2015.06.288

KOBAYASHI, M.; NUKUI, A.; KAMAI, T. Psychological impact of serial prostate-specific antigen tests in Japanese men waiting for prostate biopsy. International Journal of Clinical Oncology, v. 22, p. 174-180, 2017. Disponível em: <https://www.ncbi.nlm.nih.gov/pubmed/27631094>. Acesso em: 01 out. 2017. https://doi.org/10.1007/s10147-016-1038-1

KOHLER, N.; FRIEDRICH, M.; GANSERA, L.; HOLZE, S.; THIEL, R.; ROTH, S.; REBMANN, U.; STOLZENBURG, J.- U.; TRUSS, M. C.; FAHLENKAMP, D.; SCHOLZ, H.- J.; BRÄHLER, E. Psychological distress and adjustment to disease in patients before and after radical prostatectomy. Results of a prospective multi-centre study. European Journal of Cancer Care, v. 23, p. 795-802, 2014. Disponível em:

$<$ https://www.ncbi.nlm.nih.gov/pubmed/24661440>. Acesso em: 26 out. 2017.

https://doi.org/10.1111/ecc.12186

LEHTO, U.S.; HELANDER, S.; TAARI, K.; AROMAA, A. Patient experiences at diagnosis and phsyological well-being in prostate cancer: A Finnish national survey. European Journal of Oncology Nursing, v. 19, p. 220-229, 2015. Disponível em:

$<$ https://www.researchgate.net/publication/270291680_Patient_experiences_at_diagnosis_and_psychological_ well-being_in_prostate_cancer_A_Finnish_national_survey>. Ācesso em: $03 \overline{3}$ nov. 2017.

https://doi.org/10.1016/j.ejon.2014.10.018

MARCOLINO, J. A. M.; MATHIAS, L. A. da S. T.; FILHO, L. P.; GUARATINI, A. A.; SUZUKI, F. M.; ALLI, L. A. C. Escala Hospitalar de Ansiedade e Depressão: Estudo da Validade de Critério e da Confiabilidade com Pacientes no Pré-Operatório. Revista Brasileira de Anestesiologia, Campinas, v. 57, n. 1, p. 52-62, jan-fev. 2007. Disponível em: <http://www.scielo.br/pdf/\%0D/rba/v57n1/en_06.pdf > . Acesso em: 26 set. 2017. https://doi.org/10.1590/S0034-70942007000100006 
MESQUITA, A. C.; CHAVES, E. C. L.; AVELINO, C. C. V.; NOGUEIRA, D. A.; PANZINI, R. G.; CARVALHO, E. C. de. A utilização do enfrentamento religioso/espiritual por pacientes com câncer em tratamento quimioterápico. Revista Latino-Americana de Enfermagem. v. 21, n. 2, 07 telas, mar-abr. 2013. Disponível em: <www.scielo.br/pdf/rlae/v21n2/pt_0104-1169-rlae-21-02-0539.pdf> Acesso em: 14 mar. 2019.

NOVAES, P. E. R. S.; MOTTA, R. T.; LUNDGREN, M. S. F. S. Treatment of prostate cancer with intensity modulated radiation therapy (IMRT). Revista da Associação Médica Brasileira, v. 61, n. 1, p. 8-16, 2015. Disponível em: <http://www.scielo.br/pdf/ramb/v61n1/0104-4230-ramb-61-01-0008.pdf $>$. Acesso em: 17 mar. 2019. https://doi.org/10.1590/1806-9282.61.01.008

PASTORE, A. L.; MIR, A.; MARUCCIA, S.; PALLESCHI, G.; CARBONE, A.; LOPEZ, C.; CAMPS, N.; PALOU, J. Psychological distress in patients undergoing surgery for urological cancer: A single centre crosssectional study. Urologic Oncology: Seminars and Original Investigations, 2017. Disponível em: <https://www.ncbi.nlm.nih.gov/pubmed/28692205>. Acesso em: 15 mar. 2019.

POLIT, D.F.; BECK, C.T. Fundamentos de pesquisa em enfermagem: avaliação de evidências para a prática da enfermagem. $7^{\mathrm{a}}$ ed. Porto Alegre: Artmed, 2011. 670p.

PUNNEN, S.; COWAN, J. E.; DUNN, L. B.; SHUMAY, D. M.; CARROLL, P. R.; COOPERBERG, M. R. A longitudinal study of anxiety, depression and distress as predictors of sexual and urinary quality of life in men with prostate cancer. BJU International, v. 112, p. 67-75, 2013. Disponível em:

$<$ http://onlinelibrary.wiley.com/doi/10.1111/bju.12209/epdf>. Acesso em: 20 ago. 2017.

https://doi.org/10.1111/bju.12209

QUIJADA, P. D. S.; FERNANDES, P. A.; RAMOS, S. B.; SANTOS, B. M. O. Qualidade de vida relacionada à saúde de pacientes com câncer de próstata. Revista Cuidarte., v. 8, n. 3, p. 1826-1838, 2017. Disponível em: $<$ https://www.revistacuidarte.org/index.php/cuidarte/article/view/436/854>. Acesso em: 12 mar. 2019. https://doi.org/10.15649/cuidarte.v8i3.436

RAVI, P.; KARAKIEWICZ, P. I.; ROGHMANN, F.; GANDAGLIA, G.; CHOUEIRI, T. K.; MENON, M.; MCKAY, R. R.; NGUYEN, P. L.; SAMMON, J. D.; SUKUMAR, S.; VARDA, B.; CHANG, S. L.; KIBEL, A. S.; SUN, M.; TRINH, Q.- D. Mental health outcomes in elderly men with prostate cancer. Urologic Oncology: Seminars and Original Investigations, v. 32, p. 1333-1340, 2014. Disponível em: $<$ http://www.urologiconcology.org/article/S1078-1439(14)00168-9/fulltext>. Acesso em: 28 fev. 2019. https://doi.org/10.1016/j.urolonc.2014.05.005

SHARPLEY, C. F.; CHRISTIE, D. R. H.; BITSIKA, V.; ANDRONICOS, N. M.; AGNEW, L. L.; RICHARDS, T. M.; MCMILLAN, M. E. Comparing a genetic and a psychological factor as correlates of anxiety, depression, and chronic stress in men with prostate cancer. Support Care Cancer. v. 26, n. 9, p. $3195-$ 3200, sep. 2018. Disponível em: <https://www.ncbi.nlm.nih.gov/pubmed/29603029>. Acesso em: 15 mar. 2019. https://doi.org/10.1007/s00520-018-4183-4

SOUZA, E. M. de; LIMA, A. D. S.; DE ALMEIDA NETO, O. P.; GARCIA, F. S. e S.; CUNHA, C. M. Measurement of psycho-emotional constructs and self-management in health of patients with cancer.

Bioscience Journal, Uberlândia, v. 34, n. 2, p. 423-434, mar - apr. 2018. Disponível em: <www.seer.ufu.br/index.php/biosciencejournal/article/viewFile/39074/21922>. Acesso em: 15 mar. 2019.

TOSOIAN, J. J.; CARTER, H. B.; LEPOR, A.; LOEB, S. Active surveillance for prostate cancer: contemporary State of Practice. Nature Reviews Urology., v. 13, n. 4, p. 205-215, 2016. Disponível em: $<$ https://www.ncbi.nlm.nih.gov/pmc/articles/PMC4940050/>. Acesso em: 15 mar. 2019. https://doi.org/10.1038/nrurol.2016.45

VIEIRA, S. C.; LUSTOSA, A. M.; BARBOSA, C. N.; TEIXEIRA, J. M. R.; BRITO, L. X. E. de.; SOARES, L. F. M.; FERREIRA, M. A. T. Oncologia básica. 1. ed. Teresina, PI: Fundacao Quixote, 2012. p. 323. 
VIGNOLA, R.C.B.; TUCCI, A.M. Adaptation and validation of the depression, anxiety and stress scale (DASS) to Brazilian Portuguese. Journal of Affective Disorders, v. 155, p. 104-109, 2014. Disponível em: $<\mathrm{https}$ ://s3.amazonaws.com/academia.edu.documents/38216152/Adaptation_and_validation_of_the_depression anxiety_and_stress_scale_DASS_to_Brazilian_Portuguese.pdf?AWSAccessKeyId=AKIAIWOWYYYGZ2Y5 3UL3A\&Expires $=1509820832 \&$ Signature $=$ O5L $\bar{J}$ wiiXaiLJcWB4cFVs\%2BALGOmA\%3D\&response-contentdisposition $=$ inline $\% 3 \mathrm{~B} \% 20$ filename\%3DAdaptation_and_validation_of_the_depress.pdf $>$. Acesso em: 30 set. 2017.

WATTS, S.; LEYDON, G.; EYLES, C.; MOORE, C. M.; RICHARDSON, A.; BIRCH, B.; PRESCOTT, P.; POWELL, C.; LEWITH, G. A quantitative analysis of the prevalence of clinical depression and anxiety in patients with prostate cancer undergoing active surveillance. BMJ Open, v. 5, n. 5, 2015. Disponível em: $<\mathrm{http}$ //bmjopen.bmj.com/content/bmjopen/5/5/e006674.full.pdf>. Acesso em: 20 dez. 2017.

https://doi.org/10.1136/bmjopen-2014-006674 